\title{
Meningkatkan Hasil Belajar Tendangan Sabit Pencak Silat Melalui Modifikasi Bola Plastik
}

\author{
Kaharudin Henry Ashari ${ }^{1}$, Andy Widhiya Bayu Utomo ${ }^{2}$ \\ 1,2 Sekolah Tinggi Keguruna dan Ilmu Pendidikan Modern (STKIP) Ngawi.

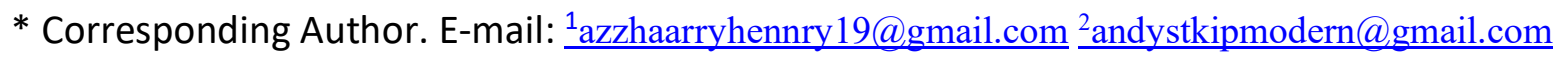

\begin{tabular}{|l|l|l|}
\hline Receive: 13/07/2021 & Accepted: 23/07/2021 & Published: 04/10/2021
\end{tabular}

\begin{abstract}
Abstrak
Penelitian ini bertujuan untuk meningkatkan hasil belajar teknik tendangan sabit di MTs Terpadu Al Firdaus Kedunggalar Kelas VII B mata pelajaran Pendidikan Jasmani Olahraga dan Kesehatan materi Pencak Silat teknik tendangan sabit. Metode penelitian ini adalah Penelitian Tindakan Kelas (PTK) yang dilakukan sebanyak dua siklus masing-masing dua pertemuan dengan jumlah 20 siswa. Penelitian ini dilaksanakan pada semester genap tahun ajaran 2020/2021. Teknik pengumpulan data yang dilakukan oleh peneliti yaitu melalui observasi, dan tes. Berdasarkan pelaksanaan tes awal mendapatkan nilai rata-rata 55 (tidak tuntas) sehingga dilakukan perbaikan. Pada tindakan perbaikan siklus I pertemuan I dan II pembelajaran teknik tendangan sabit siswa yang (tuntas) hanya 6 siswa (30\%) sementara yang tidak tuntas sebanyak 14 siswa (70\%) secara umum rata-rata mendapat nilai 57 (tidak tuntas). Melihat analisis data tersebut sehingga peneliti melanjutkan di siklus II, pada siklus II pertemuan I dan II siswa memperoleh nilai rata-rata 83 (tuntas), siswa yang tuntas sebanyak 18 (90\%) dan yang tidak tuntas 2 siswa (10\%), secara umum siswa sudah memenuhi Kriteria Ketuntasan Minimal (KKM) yaitu 75. Sehingga secara umum terjadi peningkatan yang signifikan hal ini sesuai yang diharapkan oleh peneliti sehingga peneliti tidak perlu melanjutkan penelitian.
\end{abstract}

Kata Kunci: Tendangan Sabit, Bola Plastik, Pencak Silat

Improving Learning Outcomes of Pencak Silat Crescent Kicks through Modification of Plastic Balls

\begin{abstract}
This study aims to improve learning outcomes of sickle kick technique in MTs Terpadu Al Firdaus Kedunggalar Class VII B in the subject of Physical Education, Sports and Health, on the subject of the sickle kick technique of Pencak Silat. This research method is Classroom Action Research (PTK) which is conducted in two cycles each of two meetings with a total of 20 students. This research was conducted in the even semester of the 2020/2021 school year. Data collection techniques performed by researchers, namely through observation and tests. Based on the implementation of the initial test, it got an average value of 55 (incomplete) so that improvements were made. In the corrective action cycle I of meetings I and II learning the sickle kick technique of students who (complete) only 6 students (30\%) while those who did not complete were 14 students (70\%) in general an average score of 57 (incomplete). Seeing the data analysis so that the researcher continued in cycle II, in cycle II of meetings I and II students obtained an average score of 83 (complete), students who completed were 18 (90\%) and those who did not complete were 2 students (10\%), respectively. In general, students have met the Minimum Completeness Criteria (KKM), namely 75. So that in general there is a significant increase in this as expected by the researcher so that the researcher does not need to continue the research.
\end{abstract}

Keywords: Kick Sabit, Plastic Ball, Pencak Silat

\section{Pendahuluan}

Pendidikan Jasmani Olahraga dan Kesehatan adalah salah satu mata pelajaran yang terdapat pada jenjang pendidikan mulai dari tingkat Sekolah Dasar sampai dengan Sekolah Menengah. Pendidikan jasmani olahraga dan kesehatan adalah mata pelajaran yang mampu mengembangkan individu secara menyeluluruh, tidak hanya berfokus terhadap fisik namun juga meliputi aspek mental, emosional, sosial dan spiritual (Herlina and Suherman 2020). Mata pelajarana pendidikan jasmani olahraga dan kesehatan dapat membangun karakter yang kuat dan mengembangkan sikap sportif, jujur, disiplin, bertanggung jawab dan bekerjasama melalui 
permainan-permain didalam pembelajaran pendidikan jasmani (Wijaya and Kanca 2019).

Pencak silat adalah salah satu cabang olahraga yang diajarkan didalam mata pelajaran pendidikan jasmani. Pencak memiliki berbagai macam teknik dasar diantaranya kuda-kuda, pukulan, tendangan, pasang, elakan. Teknik merupakan kumpulan unsur-unsur yang saling terkait satu dengan yang lain yang berfungsi sebagai satu kesatuan dalam mencapai usaha yang telah ditentukan (Nelson and Septri 2018). Seperti olahraga beladiri pada umumnya hal yang terpenting dalam beladiri adalah penguasaan teknik-teknik beladiri tersebut seperti teknik serangan, hindaran yang bertujuan untuk melumpuhkan musuh dan menghindar setiap serangan yang berbahaya dari lawan. Pada pelajaran pendidikan jasmani materi pencak silat keberhasilan dalam pembelajaran siswa diminta untuk menguasi teknik-tenik dasar dalam beladiri pencak silat. Salah satu teknik yang harus dikuasi adalah tendangan. Berbagai macam teknik tendangan pencak silat antara lain tendangan depan, tendangan " $T$ ", tendangan " $C$ " (sabit), tendangan belakang.

Pembelajaran pendidikan jasmani materi pencak silat tidak semua siswa mampu menguasi teknik-teknik tersebut, dikarenakan siswa mempunyai kemampuan dan bakat yang berbeda-beda untuk penguasaan pelajaran yang ada di sekolah. Sebgai seorang pengajar demi kelancaran dan keberhasilan proses belajar perlu adanya perubahan atau pengembangan model pembelajaran serta kelengkapan sarana dan prasarana. Materi pencak silat khususnya teknik tendangan siswa rata-rata kurang mampu menguasai teknik tersebut, terlebih setiap tendangan mempunyai sasaran yang berbeda.

Proses pembelajaran pendidikan jasmani olahraga dan kesehatan materi pencak silat teknik tendangan sabit ( C ) pada siswa kelas VII B MTs Terpadu Al Firdaus Kedunggalar masih tergolong rendah dari 20 siswa hanya 30\% atau 6 siswa yang tuntas, sedangkan yng belum tuntas $70 \%$ atau 14 siswa yang tidak tuntas. Sebagian besar siswa mengalami kesulitan melaksanakan tendangan sabit beberapa kelemahan yang dapat diidentifikasi yaitu kurangnya keseimbangan pada saat mengangkat kaki dan belum tepatnya tendangan mengenai sasaran setinggi perut lawan. Hal tersebut terjadi karena siswa kurang memahami teknik tendangan yang sesuai dengan peraturan pencak silat. Kurangnya alat bantu yang aman, tidak membahayakan siswa dan sesuai target yang diinginkan dapat menyebabkan kurang keberhasilannya dalam pelaksanaan proses pembelajaran teknik tendangan sabit pencak silat.

Dari permasalahan diatas peneliti memecahkan maslah dengan membuat alat bantu modifikasi bola plastik yang digantung dengan menggunakan tali sepanjang $150 \mathrm{~cm}$ atau sampai bola plastik kira-kira sejajar dengan perut lawan. Kaki yang melakukan tendangan harus mengenai sasaran bola plastik. Bola plastik yang digantung bermanfaat untuk mengetahui tinggi dan sasaran tendangan yang dilaksanakan oleh siswa dan siswa mampu melatih keseimbangan tendangan sabit tanpa

\section{Metode (15\%)}

\section{Rancangan Penelitian}

Jenis penelitian ini adalah Penelitian Tindakan Kelas (PTK) dengan tujuan memperbaiki kualitas pembelajaran serta meningkatkan proses dan hasil belajar peserta didik. PTK suati jenis penelitian yang bersifat melakukan tindakantindakan didalam kelas untuk memperbaiki dan meningkatkan pembelajaran di dalam kelas (Marlianto et al. 2018). Penelitian tindakan kelas merupakan sebuah kegiatan yang dilaksanakan oleh para pendidik atau bersama-sama (kolaborasi) dengan tujuan meningkatkan atau memperbaiki kualitas proses pembelajaran yang berlangsung didalam kelas (Moh Fajari and Suhendi 2017).

Rencana penelitian ini meliputi pembelajaran, observasi, dan tes hasil pembelajaran. Rancangan penelitian ini menggunakan 2 (dua ) siklus dengan masingmasing siklus terdiri atas dua kali pertemuan. Pertemuan pertama untuk pemberian tindakan dan pengamatan hasil belajar tendangan sabit pencak silat, pertemuan kedua untuk memantapkan tendangan sabit dilanjutkan dengan evaluasi hasil belajar tendangan sabit. Rancangan setiap siklus terdiri dari empat tahap yaitu :

1. Rencana Tindakan 
Rencana tindakan merupakan serangkaian persiapan dalam penelitian untuk meningkatkan proses pembelajaran yang meliputi observasi pembelajaran terhadap peserta didik, menyiapkan rencana pembelajaran, menyiapkan strategi pembelajaran dan menyiapkan media pembelajaran (Ngurah and Yuda 2020)

2. Pelaksanaan Tindakan

Pelaksanaan tindakan adalah suatu tindakan yang dilakukan oleh peneliti sebagai usaha untuk perbaikan, peningkatan, dan perubahan yang diinginkan oleh peneliti selama penelitian berlangsung (Supriyanto 2009). Pelaksanaan tindakan dilakukan pada siswa saat pembelajaran berlangsung yang menekankan perbaikan, kekurangan dan hambatan siswa selama proses pembelajaran.

3. Observasi/Evaluasi

Observasi adalah pengamatan atas hasil atau dampak saat pembelajaran yang dilaksanakan atau dikenakan oleh siswa (Nurgiansah 2021). Untuk tahapan ini bertujuan untuk melihat tingkat penguasaan siswa terhadap materi yang telah diberikan maka perlu adanya evaluasi.

4. Refleksi

Refleksi suatu tindakan untuk mengkaji, melihat dan memahami apa dampak dari tindakan yang telah dilakukan serta mahami apa yang terjadi sebelumnya dan apa yang telah dihasilkan setelah tindakan (Handayani and Rukmana 2020). Setalah dilakukannya evaluasi, kekurangan yang dialami oleh siswa maka peneliti mencari solusi apa yang menjadi penghambat bagi siswa dalam proses pembelajaran.

\section{Tempat, Waktu dan Subjek Penelitian}

Tempat penelitian ini dilakukan di MTs Terpadu Al Firdaus Kedunggalar kelas VII B dilaksanakan pada semester genap tahun ajaran 2020/2021 secara tatap muka. Penelitian dilakukan selama 59 hari terhitung sejak 12 Januari 2021 sampai dengan 12 maret 2021. Penelitian ini melibatkan kerjasama dengan guru PJOK dan siswa sebanyak 20 orang.

\section{Teknik Pengumpulan Data}

Teknik pengumpulan data pada penelitian ini menggunakan Tes dan Observasi.
Tes dilakukan terhadap siswa pada saat mempraktekkan teknik tendangan sabit pencak silat. Pengumpulan data menggunakan instrument penilaian tendangan sabit dengan mengintruksikan kepada seluruh siswa untuk mempraktekkan tendangan sabit. Observasi dilakukan terhadap siswa pada saat pembelajaran yang sedang berlangsung dengan mengamati perkembangan peserta didik selama proses pembelajaran teknik tendangn sabit pencak silat. Untuk lebih jelasnya dapat dilihat pada table instrument berikut :

Tabel 1. Instrument Pengumpulan data

\begin{tabular}{|c|c|c|}
\hline No. & $\begin{array}{l}\text { Jenis } \\
\text { Data }\end{array}$ & Perlakuan \\
\hline & Tes & $\begin{array}{l}\text { Tes dilakukan terhadap } \\
\text { siswa dengan melakukan } \\
\text { tendangan terhadap sasaran } \\
\text { (bola plastik) sebanyak } 10 \\
\text { kali tepat pada sasaran, dan } \\
\text { seimbang. Ketuntasan siswa } \\
\text { terhitung minimal } 60 \% \text { dari } \\
\text { jumlah ketentuan } \\
\text { tendangan yang diberikan } \\
\text { penelitiatau sebanyak } 6 \text { kali } \\
\text { tendangan. }\end{array}$ \\
\hline 2. & Observasi & $\begin{array}{l}\text { Observasi atau pengamatan } \\
\text { dilakukan terhadapa siswa } \\
\text { selama proses } \\
\text { pembelajaran, peneliti } \\
\text { mengamati perkembangan } \\
\text { siswa selama proses } \\
\text { berlangsung. }\end{array}$ \\
\hline
\end{tabular}

\section{Kriteria Keberhasilan}

Untuk tercapainya sebuah keberhasilan atau ketuntasan penelitian ini apabila mendapatkan skor 75 yang berpedoman pada nila KKM. Untuk tercapainya predikat nilai ketuntasan siswa dapat dilihat pada tabel berikut :

Tabel 2. Rentang Skor Penilaian

\begin{tabular}{cccc}
\hline No. & Skor & Predikat & Kriteria \\
\hline 1. & $86-100$ & Sangat Baik & Tuntas \\
2. & $71-85$ & Baik & Tuntas \\
3. & $56-70$ & Cukup & Tidak Tuntas \\
4. & $\leq 50$ & Kurang & Tidak Tuntas \\
\hline
\end{tabular}

\section{Hasil dan Pembahasan (70\%)}

a. Hasil

1. Siklus I 
Jurnal Edumaspul, 5(2), Year 2021 - 512

(Kaharudin Henri Azhari, Andy Widhiya Bayu Utomo)

Berdasarkan hasil analisis data dari hasil belajar tendangan sabit pada siklus I pertemuan I dan II, maka dapat dilihat persentase hasil belajar tendangan sabit pencak silat pada siswa kelas VII B MTs AI Firdaus Kedunggalar seperti tabel berikut :

Tabel 3. Hasil Belajar Tendangan Sabit Siklus I Pertemuan I dan II

\begin{tabular}{|c|c|c|c|c|c|}
\hline $\begin{array}{l}\mathbf{N} \\
\mathbf{0} .\end{array}$ & $\begin{array}{c}\text { Sko } \\
r\end{array}$ & $\begin{array}{c}\text { Predik } \\
\text { at }\end{array}$ & $\begin{array}{l}\text { Kriter } \\
\text { ia }\end{array}$ & $\begin{array}{l}\text { Juml } \\
\text { ah } \\
\text { Siswa }\end{array}$ & $\begin{array}{c}\text { Present } \\
\text { ase }\end{array}$ \\
\hline 1. & $\begin{array}{l}86- \\
100\end{array}$ & $\begin{array}{c}\text { Sangat } \\
\text { Baik }\end{array}$ & $\begin{array}{c}\text { Tunta } \\
\text { s }\end{array}$ & 1 & $5 \%$ \\
\hline 2. & $\begin{array}{l}71- \\
85\end{array}$ & Baik & $\begin{array}{c}\text { Tunta } \\
\mathrm{S}\end{array}$ & 5 & $25 \%$ \\
\hline 3. & $\begin{array}{l}56- \\
70\end{array}$ & Cukup & $\begin{array}{c}\text { Tidak } \\
\text { Tunta } \\
\text { S }\end{array}$ & 12 & $60 \%$ \\
\hline 4. & $\leq 50$ & $\begin{array}{c}\text { Kuran } \\
\mathrm{g}\end{array}$ & $\begin{array}{c}\text { Tidak } \\
\text { Tunta } \\
\text { s }\end{array}$ & 2 & $10 \%$ \\
\hline & & umlah & & 20 & $100 \%$ \\
\hline
\end{tabular}

Berdasarkan data tersebut diatas dapat dilihat nilai pada siklus I pertemuan I dan II siswa pada tes tendangan sabit pencak silat siswa yang mendapat kategori sangat baik sejumlah 1 siswa ( $5 \%)$, kategori baik sejumlah 5 siswa (25\%), kategori cukup 12 siswa (60\%), dan kategori kurang 2 siswa (10\%). Secara umum bisa dikatakan belum tuntas dikarenakan 14 siswa (70\%) dengan nilai rata-rata yaitu 57 sehingga dinyatakan belum memenuhi KKM yaitu 75 .

\section{Siklus II}

Berdasarkan hasil analisis data dari hasil belajar tendangan sabit pada siklus II pertemuan I dan II, maka dapat dilihat persentase hasil belajar tendangan sabit pencak silat pada siswa kelas VII B MTs AI Firdaus Kedunggalar seperti tabel berikut :

Tabel 4. Hasil Belajar Tendangan Sabit Siklus II Pertemuan I dan II

\begin{tabular}{cccccc}
\hline $\begin{array}{c}\text { N } \\
\text { o. }\end{array}$ & $\begin{array}{c}\text { Sko } \\
\mathbf{r}\end{array}$ & $\begin{array}{c}\text { Predik } \\
\text { at }\end{array}$ & $\begin{array}{c}\text { Kriter } \\
\text { ia }\end{array}$ & $\begin{array}{c}\text { Juml } \\
\text { ah } \\
\text { Siswa }\end{array}$ & $\begin{array}{c}\text { Present } \\
\text { ase }\end{array}$ \\
\hline 1. & $\begin{array}{c}86- \\
100\end{array}$ & $\begin{array}{c}\text { Sangat } \\
\text { Baik }\end{array}$ & $\begin{array}{c}\text { Tunta } \\
\text { s }\end{array}$ & 6 & $30 \%$ \\
& $\begin{array}{c}71- \\
2 .\end{array}$ & Baik & $\begin{array}{c}\text { Tunta } \\
\text { S }\end{array}$ & 12 & $60 \%$ \\
\hline
\end{tabular}

\begin{tabular}{cccccc}
\hline 3. & $56-$ & Cukup & Tidak & 2 & $10 \%$ \\
& 70 & Tunta & & \\
s & & \\
4. & $\leq 50$ & Kuran & Tidak & - & - \\
& & $\begin{array}{c}\text { Tunta } \\
\text { Jumlah }\end{array}$ & $\mathrm{s}$ & & \\
& & 20 & $100 \%$ \\
\hline
\end{tabular}

Berdasarkan data tersebut diatas dapat dilihat nilai pada siklus II pertemuan I dan II siswa pada tes tendangan sabit pencak silat siswa yang mendapat kategori sangat baik sejumlah 6 siswa ( $30 \%)$, kategori baik sejumlah 12 siswa (60\%), kategori cukup 2 siswa (10\%), Secara umum siswa dinyatakan tuntas dikarenakan 18 siswa (90\%) dan siswa yang tidak tuntas sebanyak 2 orang (10\%). Sehingga dengan demikian pada siklus II dinyatakan tuntas dengan nilai rata-rata yaitu 83 sehingga sudah memenuhi nilai KKM yaitu 75 .

\section{b. Pembahasan}

Berdasarkan analisis data dari hasil belajar tendangan sabit pencak silat pada siswa kelas VII B MTs Terpadu Al Firdaus pada Siklus I dalam kategori cukup (tidak tuntas) masih ditemukan 12 siswa yang tidak tuntas dengan nilai rata-rata 57. Adapun kendala-kendala yang di hadapi siswa dalam proses pembelajaran tendangan pencak silat pada siklus I adalah: kaki yang melakukan tendangan tidak lurus, kaki yang sebagai tumpuan kurang menekuk menyebabkan kurang seimbang dan kaki yang menendang mengnai bola plastik (sasaran) belum tepat atau terlalu rendah.

Berdasarkan kendala-kendala diatas, maka tindakan yang harus diperlakukan adalah memberikan pemahaman yang harus dilakukan pada siswa pada saat mempraktekkan tendangan sabit, memberikan contoh tendangan sabit yang baik dan benar pada siswa, dan memberikan motivasi pada siswa supaya siswa semangat dalam melaksanakan belajar tendangan sabit.

Sedangakan hasil analisis data dari hasil belajar tendangan sabit pada siklus II siswa tergolong pada kategori sangat baik (tuntas) siswa yang tuntas dalam belajar tendangan sabit yaitu sebanyak 18 siswa (90\%) dengan nilai ratarata 83. Walaupun masih ditemukan 2 siswa yang belum tutas namun pada uraian tersebut tingkat penguasaan materi tendangan sabit pencak silat pada siklus II sudah memenuhi standar ketuntasan secara klasikal yaitu diatas 75 sesuai 
dengan Kriteria Ketuntasan Minimal (KKM) pada siswa MTs Terpadu Al Firdaus kelas VII B, sehingga pelaksanaan penelitian ini dihentikan sesuai dengan rancangan peneliti yang telah ditentukan sebelumnya. Berdasarkan penelitian ini membuktikan bahwa penggunaan media bola plastik sangat efektif untuk meingkatkan hasil belajar tendangan sabit pencak silat.

\section{Simpulan}

Berdasarkan hasil penelitian di kelas VII B MTs Terpadu Al Firdaus Kedunggalar, peningkatan belajar tendangan sabit pencak silat melalui modifikasi bola plastik dapat meningkatkan tendangan sabit pada pembelajaran teknik tendangan sabit pencak silat, ini dibuktikan dari hasil penelitian yang diperoleh pada siklus I dan II masing-masing dua pertemuan terjadi peningkatan sangat baik sesuai yang diharapkan peneliti.

\section{Daftar Pustaka}

Penyusunan Daftar Pustaka yang mengikuti teknik yang standar harus dilakukan secara baku dan konsisten.

Handayani, Sri Lestari, and Diki Rukmana. 2020. "Peningkatan Kemampuan Menulis Karya IImiah Guru Melalui Pelatihan Penelitian Tindakan Kelas Bagi Guru SD." Publikasi Pendidikan 10(1):8.

doi: 10.26858/publikan.v10i1.9752.

Herlina, Herlina, and Maman Suherman. 2020. "Potensi Pembelajaran Pendidikan Jasmani Olahraga Dan Kesehatan (Pjok) Di Tengah Pandemi Corona Virus Disease (Covid)-19 Di Sekolah Dasar." Tadulako Journal Sport Sciences And Physical Education 8(1):1-7.

Marlianto, Fani, Yarmani, Ari Sutisyana, and Defliyanto. 2018. "Analisis Tendangan Sabit Pada Perguruan Pencak Silat." Jurnal IImiah Pendidikan Jasmani 2(2):179-85.

Moh Fajari, Agung, and Hendi Suhendi. 2017. "Penerapan Model Pembelajaran Kooperatif
Tipe Jigsaw Menggunakan Media Karet Ban Untuk Meningkatkan Keterampilan Gerak Kaki Tendangan Sabit Dalam Pembelajaran Pencak Silat." TEGAR: Journal of Teaching Physical Education in Elementary School 1(1):75. doi: 10.17509/tegar.v1i1.8677.

Nelson, Sonya, and Septri Septri. 2018. "Pengembangan Model Pembelajaran Teknik Dasar Pencak Silat Berbasis Multimedia Di Fakultas IImu Keolahragaan Universitas Negeri Padang." Jurnal Stamina 1(1):346-58.

Ngurah, Gusti, and Arya Yuda. 2020. " Peningkatan Hasil Belajar Penjasorkesmateri Tendangan Pencak Silatmelalui Alat Bantu Tali Bentang " Jurnal Mitra Pendidikan ( JMP Online ). 4(3):99-113.

Nurgiansah, T. Heru. 2021. "Pelatihan Penelitian Tindakan Kelas Bagi Guru Pendidikan Kewarganegaraan Di Sekolah Menengah Atas Se-Kabupaten Bantul." 2(1):28-33. doi: 10.31949/jb.v2i1.566.

Supriyanto, Achmad. 2009. "Peningkatan Kemampuan Guru Dalam Penulisan Karya IImiah Melalui Pelatihan Penelitian Tindakan Kelas." (1):1-7.

Wijaya, Made Agus, and I. Nyoman Kanca. 2019. "Media Pembelajaran Aktivitas Pengembangan PJOK Untuk Pendidikan Dasar Dan Menengah." JOSSAE : Journal of Sport Science and Education 4(1):1. doi: 10.26740/jossae.v4n1.p1-6.

\section{Profil Penulis}

Nama saya adalah Kaharudin Henry Ashari saya lahir di Ngawi 13 Juni 1998 saat ini saya adalah mahasiswa STKIP Modern Ngawi tahun angkatan 2017 jurusan PENJASKESREK. Saat ini saya sedang menhadapi semester akhir atau sedang menjalani skripsi. Bapak Andy Widhiya Bayu Utomo adalah dosen pembimbing saya. 